\title{
気候条件に配慮した住宅の維持 保全コストに関する研究 \\ A STUDY ON THE HOUSING MAINTENANCE COST ADAPTED TO CLIMATE CONDITIONS
}

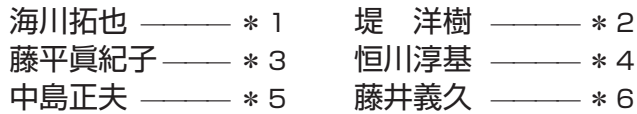

キーワード :

長期優良住宅，維持保全計画，気候条件，維持保全コスト，地域差

Keywords:

Long-life quality housing, Maintenance program, Climate condition, Maintenance cost, Regional difference

1.はじめに

近年、住宅分野ではストック社会の実現を目指した様々な取組み が行われているが、例えば長期優良住宅の申請において維持保全計 画の作成が要求されるなど、維持保全計画の重要性が見直されてい る。中長期的な維持保全費用の確保を促寸面から見ても適切な維持 保全計画の策定は不可欠であるが、地域によって気象条件が大きく 異なる日本では、気候条件の違いによる劣化進行を踏まえ維持保全 計画を策定することが必要となる。しかし現状の維持保全計画の作 成は、基本的に各企業や工務店に任されているため、地域による気 候差を反映した維持保全計画であるかは定かでない。1)2

そこで本研究では、長期優良住宅の維持保全計画をもとに、誰で も簡易かつ適切に住宅の建設地の気候条件を配慮した維持保全コス 卜を算出する手法を検討する。なお本研究では、60 年間は躯体の補 修·交換が不必要な木造戸建住宅の維持管理を前提に検証を行う。

\section{2. 研究概要}

まず各地域の気候要因が住宅の各部位の劣化に影響を与える度合 いを評価し、5 つの地域区分を作成する。地域区分を明示すること で、住宅の建設地でどの程度維持保全に力を入れるべきか容易に判 断が可能となる。

次に、地域区分別に 60 年間のメンテナンスや交換に必要なコスト (以下「維持保全コスト」)の算出を行う。本研究では大手住宅メーカ 一の協力を得て、実際に建てられた 84 件の住宅(以下「物件サンプ ル」)の維持保全計画から、適切な維持保全に必要になる維持保全コ

Takuya UMIKAWA — $* 1$
Makiko FUJIHIRA $-* 3$
Masao NAKAJIMA — $* 5$

Hiroki TSUTSUMI - $* 2$ Junki TSUNEKAWA $-* 4$

Yoshihisa FUJII — $* 6$

For appropriate maintenance program, it is necessary to know the regional differences of the climate condition that affect building deteriorations. This study classified the nation into 5 regional categories of the housing maintenance cost adapted to the climate conditions. Moreover, this study suggested 2 methods that of simple and detailed calculations of maintenance cost between 60 years, for comparing with current method as required for long-life quality housing. In the result, the methods enabled to show not only the standard maintenance cost but also the direction of maintenance program suitable for the housing location.

ストを算出する基準コストを設定する。

最後に、設定した基準を用いて算出した維持保全コストと現状の 維持保全計画による維持保全コストを比較することで、本研究で提 案する維持保全コストの策定手法の有効性を検証する。

\section{3. 気候条件による地域区分の作成}

\section{1 気候条件が住宅劣化に及ぼす影響}

日本全国を気候条件により 5 つの地域区分に分類するために、住 宅の劣化に影響を及ぼすと考えられる気候要因を選定し、全国の地 上気候観測所 (以後「観測所」)の気候データを収集した。

本研究では、住宅の劣化に大きな影響を与えると考えられる気候 要因として、年間降水量 (以下「降水量」)、年間平均湿度 (以下「湿度」)、 年間最大積雪量 (以下「積雪量」)、年間最低気温 (以下「最低気温」)、 地下シロアリの分布 (以下「シロアリ分布」)の 5 要因を選定した注 1 。 なお降水量·湿度・積雪量・最低気温についてはアメダス (地域気象観 測システム ${ }^{3)}$ 、シロアリ分布については公益社団法人日本しろあり 対策協会の資料 ${ }^{4)}$ を参考にした。

その後、各観測所の気候データを 3 段階で評価（以下「気候評価」） した。なお事前のヒアリングの結果から、維持保全計画に記載され ている金額や周期は東京を基準に設定していることが判明したため、 各気候評価は東京の気象条件と比較し、東京と同等と考えられるデ ータは【2】、厳しいと考えられるデータは【3】、緩いと考えられる データは【1】と設定した。なお各観測地の評価基準を表 1 、評価例 を表 2 に示す。

\footnotetext{
(株)合人社計画研究所 修士 (工学)

(下 730-0036 広島市中区袋町 4 番 31 号)

前橋工科大学 准教授・博士 (工学)

奈良女子大学 講師・博士（学術）

前橋工科大学 修士 (工学)

関東学院大学 教授・博士 (工学)

京都大学 准教授・農博
}

\author{
GOJIN CO., LTD., M. Eng. \\ Assoc. Prof., Maebashi Institute of Technology, Dr. Eng. \\ Instructor, Nara Women's Univ., Ph. D. \\ Maebashi Institute of Technology, M. Eng. \\ Prof., Kanto Gakuin Univ., Dr. Eng.
}

Assoc. Prof., Kyoto Univ., Dr. Agr. 


\section{2 住宅部位からみた気候要因の影響}

住宅の部位ごとに、どの気候要因が劣化を促進させる可能性が高 いか検討し、メンテナンスの重要性を評価する。なお対象となる住 宅部位は、維持保全計画で金額・周期の設定が行われている 16 部位 (以下「保全項目」)とする。

まず各保全部位のうち、性能・要求条件に合わせ「外部」「給湯器」 「エアコン」「防蟻処理」「その他」の 5 つに分類（以下「保全分類」）し、 対応する気候要因を検討した(表 3)。さらに保全項目ごとに関係す る気候評価の平均值を算出し、メンテナンス項目の重要性を評価 (以 下「保全評価」)した (表 4)。

以上の結果から、各観測所の気候条件において東京よりも維持保 全の重要性が高い保全分類が明らかになった。

\section{3 地域区分に分類する評価手法}

保全評価の結果をもとに地域区分に分類するため、全国の地上気 候観測所 148 地点 (以下「観測点」) における気象データから算出した 保全評価を統合した係数(以下「地域係数」)を算出する。

まず、維持保全計画が東京基準になっていることから、極端に維 持保全コストが高いもしくは低い物件を除く東京 10 物件の維持保 全コストの平均を保全分類別に求め、全体の維持保全コストに対寸 る割合を算出した結果、外部 $44 \%$ 、給湯器 $8 \%$ 、エアコン $26 \%$ 、防蟻 処理 7\%、その他 $15 \%$ であった。

そこで各保全評価を全体の維持保全コストに対する割合を重みづ けした加重平均により、観測点の地域係数を算出する (表 4)。例え ば浜松 (外部 2.25 、給湯器 2.00、エアコン 2.33、防蟻処理 3.00 、そ の他 2.00)の地域係数は 2.26 と算出される(式(1))。

$(2.25 \times 44 \%)+(2.00 \times 8 \%)+(2.33 \times 26 \%)$

$+(3.00 \times 7 \%)+(2.00 \times 15 \%)=\underline{2.26}$

\section{4 地域区分の設定とマッピング}

地域係数の最高值は「奥日光」の 2.78 、最小值は「東京」他 6 地点の 2.00 であった。地域係数が大きい地域ほど相対的に住宅の劣化が進 みやすい条件がそろっていると考えられることから、2.78 と 2.00 の間を 5 区分に等分し、地域係数が最も小さな区分を地域 1 、最も 大きな区分を地域 5 と設定する。

次に 148 測定点の地域係数をもとに日本の全地域における地域区 分の分布をマッピングするため、観測点ごとに位置情報と地域区分 （地域 1 から地域 5) を地理情報システム (GIS) に入力し、ラスタ解析 による内挿補間を行った。内挿補間とは、限られた数のサンプルデ ータ・ポイントからラスタ (2 次元平面を細い格子(セル)に分割して 表現されたデータ)内の一連のセル值を予測する手法である。この操 作により全国の地域区分を面的に表現することが可能となるため、 観測点以外の地域についても地域区分が推測可能となる。

なお補完方法はスプライン法(標高や気温などゆるやかに変化す る補間結果を得るのに適している補完方法)を用いる。ラスタ解析に よるマッピングの結果、以下の傾向が明らかになった(図 1)。

・北海道全域や北陸地方の海沿い、東北地方の内陸部などで地域係 数が大きい傾向が見られる。これらの地域では維持保全コストを 他の地域よりも高く設定することが望ましいと考えられる。
・西日本の全域、特に瀬戸内海周辺は、地域係数が小さい傾向が見 られる。これらの地域では維持保全コストを東京都同程度に設定 しても問題ないと考えられる。

表 1 気候評価の基準

\begin{tabular}{|c|c|c|c|}
\hline 気候要因評価 & 1 & 2 & 3 \\
\hline 降水量 & $1,000 \mathrm{~mm}$ 未満 & $\begin{array}{l}\text { 1, } 000 \mathrm{~mm} \text { 以上 } \\
2,000 \mathrm{~mm} \text { 未満 }\end{array}$ & 2, $000 \mathrm{~mm}$ 以上 \\
\hline 湿度 & & 68\%未満 & $68 \%$ 以上 \\
\hline 積雪量 & & $33 \mathrm{~cm}$ 未満 & $33 \mathrm{~cm}$ 以上 \\
\hline 最低気温 & $0^{\circ} \mathrm{C}$ 以上 & $\begin{array}{l}-10^{\circ} \mathrm{C} \text { 以上 } \\
0^{\circ} \mathrm{C} \text { 末満 } \\
\end{array}$ & $-10^{\circ} \mathrm{C}$ 未満 \\
\hline シロアリ分布 & 生息なし & ヤマトシロアリ & $\begin{array}{c}\text { ヤマトシロアリ } \\
\text { イエシロアリ }\end{array}$ \\
\hline
\end{tabular}

表 2 気候評価の設定 (一部)

\begin{tabular}{|c|c|c|c|c|c|c|c|c|c|c|}
\hline \multirow[b]{2}{*}{ 地点名 } & \multicolumn{5}{|c|}{ 気候要因 } & \multicolumn{5}{|c|}{ 気候評価 } \\
\hline & $\begin{array}{c}\text { 降水 } \\
\text { 量 }\end{array}$ & 湿度 & $\begin{array}{c}\text { 積雪 } \\
\text { 量 }\end{array}$ & $\begin{array}{l}\text { 最低 } \\
\text { 気温 }\end{array}$ & $\begin{array}{l}\text { シ吅 } \\
\text { 分布 }\end{array}$ & \begin{tabular}{||c|}
$\mid$ 降水 \\
量
\end{tabular} & 湿度 & \begin{tabular}{|c|} 
積雪 \\
量
\end{tabular} & $\begin{array}{l}\text { 最低 } \\
\text { 気温 }\end{array}$ & $\begin{array}{l}\text { 泇师 } \\
\text { 分布 }\end{array}$ \\
\hline 奥日光 & 2,213 & 76.9 & 39.7 & -13.31 & 㠴 & 3 & 3 & 3 & 3 & 2 \\
\hline 函館 & 1,140 & 72.2 & 45.0 & -11.62 & ヤマ卜 & 2 & 3 & 3 & 3 & 2 \\
\hline 高田 & 2,780 & 75.9 & 95.0 & -5.4 & 㠴 & 3 & 3 & 3 & 2 & 2 \\
\hline 札幌 & 1,100 & 67.8 & 92.5 & -12.16 & 㠴 & 2 & 2 & 3 & 3 & 2 \\
\hline 青森 & 1,413 & 73.9 & 107.0 & -8.3 & 㠴 & 2 & 3 & 3 & 2 & 2 \\
\hline 鳥取 & 1,848 & 72.7 & 34.7 & -3.53 & 訃 & 2 & 3 & 3 & 2 & 2 \\
\hline 浜松 & 1,761 & 68.7 & 0.0 & -1.51 & ヤマト・任 & 2 & 3 & 2 & 2 & 3 \\
\hline 山口 & 1,898 & 69.8 & 7.5 & -3.92 & ヤマト・任 & 2 & 3 & 2 & 2 & 3 \\
\hline 大阪 & 1,239 & 62.8 & 1.8 & -1.19 & ヤマト・任 & 2 & 2 & 2 & 2 & 3 \\
\hline 東京 & 1,628 & 59.4 & 3.0 & -0.59 & 㠴 & 2 & 2 & 2 & 2 & 2 \\
\hline
\end{tabular}

\section{表 3 保全分類と気候要因の関係}

\begin{tabular}{|c|c|c|c|}
\hline 保全項目 & 保全分類 & 気候要因 & 重み \\
\hline \hline $\begin{array}{c}\text { 【基礎·屋根】バルコニー】玄関ドア】 } \\
\text { 【外装部品・軒天】サッシ・勝手ロドア】 } \\
\text { 【雨戸・シャッターボックス】雨樋】 }\end{array}$ & 外部 & $\begin{array}{c}\text { 降水量、湿度、 } \\
\text { 積雪量、最低気温 }\end{array}$ & $44 \%$ \\
\hline 【給湯器・その他ボイラー】 & 給湯器 & 積雪量、最低気温. & $8 \%$ \\
\hline 【全館空調・エアコン】 & エアコン & 湿度、積雪量、気温 & $26 \%$ \\
\hline 【防蟻処理】 & 防蟻処理 & シロアリリ分布 & $7 \%$ \\
\hline $\begin{array}{c}\text { 【外部足場】【廃棄物処理·他】 } \\
\text { 【ユニットバス】【調理コンロ】【排水管】 }\end{array}$ & その他 & - & $15 \%$ \\
\hline
\end{tabular}

\section{表 4 保全評価の算出方法 (一部)}

\begin{tabular}{|c|c|c|c|c|c|c|c|}
\hline \multirow[b]{2}{*}{ 地点名 } & \multicolumn{5}{|c|}{ 保全評価 } & \multirow{2}{*}{$\begin{array}{l}\text { 地域 } \\
\text { 係数 }\end{array}$} & \multirow{2}{*}{$\begin{array}{l}\text { 地域 } \\
\text { 区分 }\end{array}$} \\
\hline & 外部 & $\begin{array}{c}\text { 給湯 } \\
\text { 器 }\end{array}$ & $\begin{array}{l}\text { エア } \\
\text { コン }\end{array}$ & $\begin{array}{l}\text { 防蟻 } \\
\text { 処理 }\end{array}$ & $\begin{array}{c}\text { その } \\
\text { 他 }\end{array}$ & & \\
\hline 奥日光 & 3.00 & 3.00 & 3.00 & 2.00 & 2.00 & 2. 78 & 5 \\
\hline 函館 & 2. 75 & 3.00 & 3.00 & 2.00 & 2.00 & 2.67 & 5 \\
\hline 高田 & 2.75 & 2.50 & 2.67 & 2.00 & 2.00 & 2.55 & 4 \\
\hline 札幌 & 2.50 & 3.00 & 2.67 & 2.00 & 2.00 & 2. 48 & 4 \\
\hline 青森 & 2.50 & 2.50 & 2.67 & 2.00 & 2.00 & 2. 43 & 3 \\
\hline 鳥取 & 2.50 & 2.50 & 2.67 & 2.00 & 2.00 & 2.43 & 3 \\
\hline 浜松 & 2.25 & 2.00 & 2.33 & 3.00 & 2.00 & 2.26 & 2 \\
\hline 山口 & 2.25 & 2.00 & 2.33 & 3.00 & 2.00 & 2.26 & 2 \\
\hline 大阪 & 2. 00 & 2. 00 & 2.00 & 3.00 & 2.00 & 2.07 & 1 \\
\hline 東京 & 2. 00 & 2.00 & 2.00 & 2.00 & 2.00 & 2.00 & 1 \\
\hline
\end{tabular}




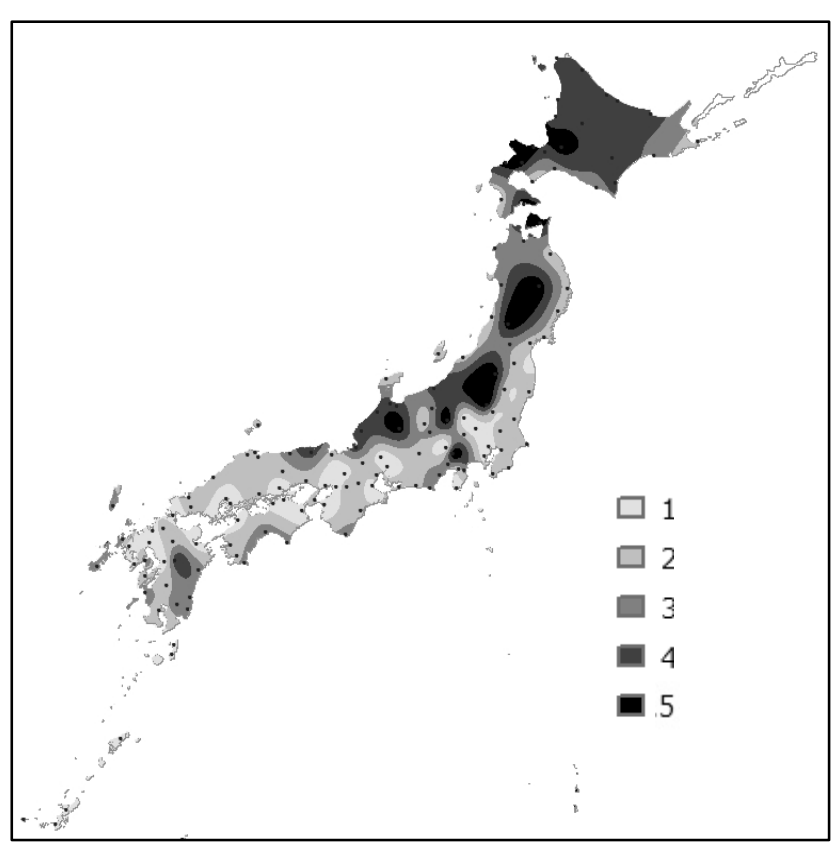

図 1 地域区分の分布

\section{4. 地域区分に適した維持保全コストの算出}

\section{1 地域区分別にみた維持保全コスト}

住宅の維持管理計画は、住宅の部材の耐久性と交換時期の関係か ら設定することが可能である。交換時期が同程度であれば部材の耐 久性を調整することで、部材の耐久性が同程度であれば交換時期を 調整することで、住宅の気象条件に適した維持保全計画が設定可能 である。しかし、各部位の耐久性を簡易かつ定量的に評価すること は困難なため、本研究では部材の耐久性を維持保全コストに置き換 えることで維持保全計画の妥当性を検証する。

そこで維持保全コストが各地域区分でどの程度異なるか把握する ため、地域区分ごとに現状でどの程度の維持保全コストが計画され ているかを調査する。

まず物件サンプルについても建設地の地域係数から地域区分を決 定する。なお建設地が明らかな場合は建設地に最も近い気象観測所 の地域係数を、建設地が明確でない場合は建設された都道府県の県 庁所在地の地域係数を用いる。

次に地域区分ごとの基準となる維持保全コストを設定する。なお 各物件サンプルの維持保全コストは、部位ごとに面積・幅·箇所数な ど(以下「保全数量」) とメンテナンスの単価(以下「保全単価」)により 構成され、この積から各保全項目の 60 年間の維持保全コストを算出 することが可能な維持保全計画が設定されている。しかし物件によ りプランや規模が異なるため、そのままでは地域区分ごとの比較は 難しい。そこで保全単価は各物件サンプルと同じ単価を用いるが、 保全数量は東京都の物件サンプルの1つ(以下「物件 A」) に揃える(表 5) ことで、同プラン・規模の物件の場合の維持保全コスト (以下「換算 コスト」)を算出し、地域区分別に換算コストの平均を比較した。

その結果、物件 A に対する各地域区分の平均換算コストの割合(以 後「保全係数」は、地域 1 では 102\%、地域 2 では 104\%、地域 3 で は $115 \%$ 、地域 4 では 118\%となった(表 6)。なお地域 5 については 該当する物件サンプルが入手できなかった。そこで地域 1 から地域 4 までの保全係数の分布を近似直線を用いて整理するとともに、地
域 5 の保全係数を推計した。その結果、決定係数が 0.971 の回帰直 線(図 2)が得られたことから、地域 1 は 101\%、地域 2 は 107\%、地 域 3 は $113 \%$ 、地域 4 は $119 \%$ 、そして地域 5 は 125\%を各地域区分 の基準保全係数とする。

以上の結果から、地域係数が高い地域に建設された住宅ほど維持 保全コストを高く設定する必要があること、また気候条件が最も厳 しい地域 5 では維持保全コストを東京(地域 1)に比べて $1 / 4$ 程度高 めに設定することが望ましいことが明らかになった。

なお物件 $\mathrm{A} の \mathrm{~m}^{2}$ (延床)当りの 60 年間の維持保全コストは 169,666 円であるため、地域 1 は $\mathrm{m}^{2}$ 当り 60 年間で 17 万円、地域 2 は 18 万 円、地域 3 は 19 万円、地域 4 は 20 万円、地域 5 は 21 万円程度の維 持保全コストを見込んだ維持保全計画が適当だと考えられる(表 7)。

表 5 物件 A の保全項目

\begin{tabular}{|c|c|c|c|c|c|}
\hline \multirow{2}{*}{ 保全項目 } & \multicolumn{2}{|c|}{ 保全量 } & \multirow{2}{*}{ 保全項目 } & \multicolumn{2}{|c|}{ 保全量 } \\
\hline & 単位 & 数量 & & 単位 & 数量 \\
\hline 基礎·屋根 & $\mathrm{m}^{2}$ & 60.1 & 給湯器·ボ价- & 台 & 1 \\
\hline バルコニー & $\mathrm{m}^{2}$ & 9.9 & 全館空調・エアコン & 式 & 1 \\
\hline 外壁 & $\mathrm{m}^{2}$ & 208.8 & 防蟻処理 & $\mathrm{m}^{2}$ & 54.4 \\
\hline 外装部品·軒天 & $\mathrm{m}^{2}$ & 42 & 外部足場 & $\mathrm{m}^{2}$ & 107.2 \\
\hline 玄関ドア & 本 & 1 & 廃棄物処理 · 他 & $\mathrm{m}^{2}$ & 107.2 \\
\hline サッシ・勝手ロドア & 本 & 1 & ユニットバス & 䇢所 & 1 \\
\hline 雨戸・シかッターボックス & 䇢所 & 3 & 調理コンロ & 台 & 1 \\
\hline 雨樋 & $\mathrm{m}$ & 28.8 & 排水管 & 式 & 1 \\
\hline
\end{tabular}

表 6 物件 A 換算の維持保全コスト

\begin{tabular}{|c||c|c|c|}
\hline 地域区分 & サンプル数 & 基準換算コスト & 基準/物件 A \\
\hline \hline 物件 A & 1 & $¥ 18,544,488$ & - \\
\hline \hline 地域 1 & 28 & $¥ 18,851,779$ & $102 \%$ \\
\hline 地域 2 & 27 & $¥ 19,239,962$ & $104 \%$ \\
\hline 地域 3 & 18 & $¥ 21,363,269$ & $115 \%$ \\
\hline 地域 4 & 11 & $¥ 21,865,486$ & $118 \%$ \\
\hline 地域 5 & 0 & - & - \\
\hline
\end{tabular}

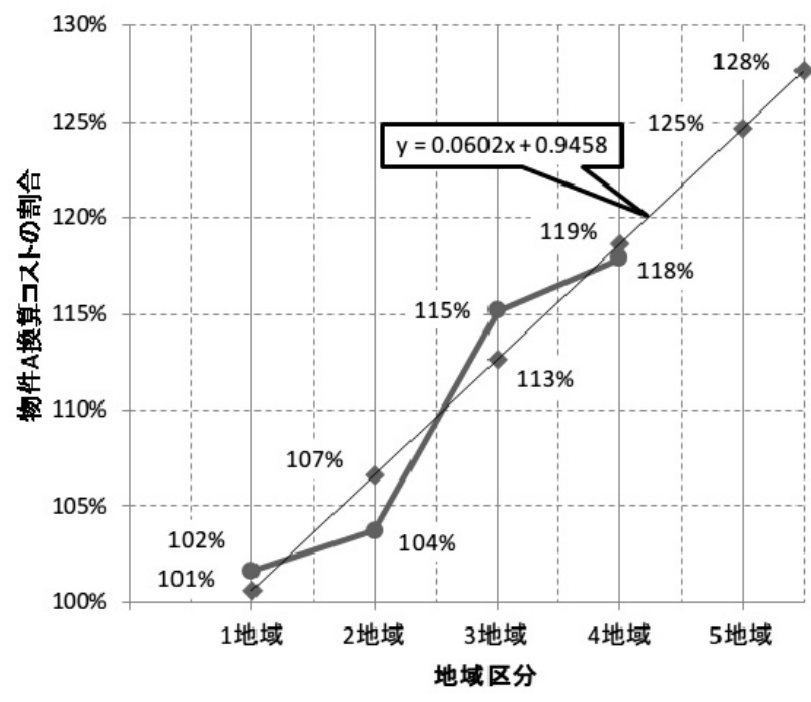

図 2 回帰式からみた換算コストの推計 
表 7 地域区分別にみた $\mathrm{m}^{2}$ (延床) 当り維持保全コスト

\begin{tabular}{|c|c|c|c|}
\hline 地域区分 & 物件 A 延床面積単価 & 気候係数 & 概算コスト単価 \\
\hline 地域 1 & \multirow{5}{*}{$¥ 169,666$} & 1.01 & $¥ 170,684$ \\
\hline 地域 2 & & 1.07 & $¥ 180,898$ \\
\hline 地域 3 & & 1.13 & $¥ 191,112$ \\
\hline 地域 4 & & 1.19 & $¥ 201,326$ \\
\hline 地域 5 & & 1.25 & $¥ 211,540$ \\
\hline
\end{tabular}

\section{2 部位別に見た維持保全コスト}

保全係数を用いることで、地域の気候差を考慮した維持保全コス トの概算は可能になるが、実際には各部位ごとに必要となる維持保 全コストは住宅の建設地によって異なる。そこで保全評価と保全係 数の関係から各部位の保全係数を逆算し、維持保全コストの部位別 標準単価を求める。

ここで部位別の保全係数は物件 A の保全単価を基準としているた め、保全評価が 2.00 の部位は保全係数が 1.00 になるよう設定する と、部位別の保全係数は式 (2)、気候係数は式(3) で算出できる。

$$
\begin{aligned}
& B_{n}=a\left(H_{n}-2\right)+1 \cdots \cdots(2) \\
& \text { ただし、 } B_{n} \text { : 部位別の保全係数 } \\
& H_{n} \text { : 部位別の保全評価 } a: \text { 定数 } \\
& K=\sum\left\{a\left(H_{n}-2\right)+1\right\} b_{n} \\
& \text { ただし、 } K \text { : 気侯係数 } \\
& b_{n} \text { : 維持保全コストに占める保全分類の割合 }
\end{aligned}
$$

なお保全係数が最も高く、最も維持保全コストが割高になると考 えられる「奥日光」の保全係数は、地域 5 の $125 \%$ より高く設定する 必要があることから、保全係数の基準を求めた回帰式の変数 $\mathrm{x}$ に 5.5 を代入した $128 \%$ を採用する。式(3)に「奥日光」の気候係数 1.28 を代 入すると定数 $\alpha$ は 0.36 と算出されることから、部位別の保全係数の 算出は式(4)となる。

$$
B_{n}=0.36 H_{n}+0.29
$$

式(3)、式(4)を用いると部位別に保全係数が求まるため、気象条 件に適した維持保全コストを部位別に評価することが可能になる。

\section{5. 現状の維持保全コストとの比較}

以上の検討により、60 年間の維持保全コストを 2 種類の算出方法 から求めることが可能となった。ここでは現状の維持保全コス卜と 比較することで、現状の維持保全コストが適切と考えられる維持保 全コストからどの程度乘離しているか把握する。

まず物件サンプルの地域区分ごとの $\mathrm{m}^{2}$ 当り標準維持保全コスト （表 7)に物件サンプルの延床面積を掛け合わせ算出した維持保全コ スト (以下「概算コスト」)を求める。同様に部位別保全係数から求め た部位別 $\mathrm{m}^{2}$ 当り標準維持保全コストに各部位の数量を掛け合わせ合 算した維持管理コスト(以下「詳細コスト」)を求める。

この概算コストと詳細コストを地域区分別に平均し、現状の維持
保全コスト (以後「現状コス卜」) と比較する。その結果、概算コスト は気象条件が厳しい地域区分ほど現状コストよりも高くなる傾向が 見られる。一方、詳細コストは地域区分に係わらず現状コストに比 べ 1 割程度高い傾向が見られる(表 8 )。

以上の結果から、概算コス卜は地域区分と延床面積から簡易に算 出できるが、プランの違いに対応できず維持管理コストが高めに算 出される傾向が見られる。一方、プランの違いにも対応している詳 細コストは適切な維持管理コストが算出されていると考えられるこ とから、現状コストは全体的に低く抑えられていると考えられる。

\section{表 8 現状コストとの比較}

\begin{tabular}{|c||c||c|c||c|c|}
\hline 地域区分 & 現状コスト & 概算コスト & $\begin{array}{c}\text { 現状/ } \\
\text { 概算 }\end{array}$ & 詳細コスト & $\begin{array}{c}\text { 現状/ } \\
\text { 詳細 }\end{array}$ \\
\hline \hline 地域 1 & $¥ 20,942,272$ & $¥ 21,784,030$ & $99 \%$ & $¥ 23,286,121$ & $91 \%$ \\
\hline 地域 2 & $¥ 21,995,787$ & $¥ 26,619,610$ & $85 \%$ & $¥ 24,301,037$ & $91 \%$ \\
\hline 地域 3 & $¥ 23,657,315$ & $¥ 29,897,709$ & $82 \%$ & $¥ 26,336,899$ & $90 \%$ \\
\hline 地域 4 & $¥ 24,327,327$ & $¥ 34,880,599$ & $68 \%$ & $¥ 25,429,567$ & $93 \%$ \\
\hline 地域 5 & - & & - & - & - \\
\hline
\end{tabular}

\section{6. まとめ}

住宅の劣化に影響を及ぼす気候要因を考慮して全国を 5 地域区分 に分類しマッピングを行うことで、維持保全コストを高く設定す心゙ き地域が誰にでも容易に判明する資料を作成した。

また 60 年間の維持保全コストを地域区分と延床面積から概算す る簡易な算出手法と、部位ごとに適切な維持保全を積み上げる詳細 な算出手法から、住宅の建設地の気候条件に適切な維持保全コスト の基準を提示した。

その結果、これら 2 つの算出結果をふまえ現状の維持保全コスト 妥当性を検討することが可能となった。また維持保全コストの基準 をもとに、部材の耐久性もしくは交換時期を調整することも可能だ ろう。今後は劣化調查などによる本成果の精度の向上に加え、塩害 など局地的な劣化現象や住宅の利用方法の違いにも配慮することで、 より劣化実態に即した維持保全計画の策定手法を検証したい。

\section{謝辞}

本研究は平成 24 年度木造長期優良住宅の総合的検証事業 (国土交 通省助成事業)の一環として行った。ここに記して謝意を示す。

\section{注}

注 1）塩害被害は海岸沿いで発生する局部的な劣化現象とみなし本研究では除外した

\section{参考文献}

1) 木造長期優良住宅の総合的検証委員会耐久性分科会：木造長期優良住宅の 総合的検証委員会耐久性分科会平成 22 年度報告書

2) 海川拓也, 堤 洋樹, 水出有紀, 中島正夫, 藤平眞紀子, 藤井義久: 長期優 良住宅の維持保全計画の最適化に関寸る研究一気候差を考慮したマニュア ル化の検討一, 第 28 回建築生産シンポジウム論文集, pp. 273-278, 2012.7 3) 気象庁: アメダス (過去の気象データ)

http://www. data. jma. go. jp/obd/stats/etrn/index. php

4) 公益社団法人日本しろあり対策協会ホームページ

http://www. hakutaikyo. or. jp/

[2013 年 2 月 18 日原稿受理 2013 年 4 月 1 日採用決定 $]$ 